\section{Viscoelastic agents in ocular surgery}

SIR, - Lavin and Khaw have drawn attention to the use of viscoelastic agents for improving visualisation during ocular surgery. 'One problem that occurs is when during ocular examination or surgery the internal view is obscured by phenylephrine epitheliopathy. ${ }^{2}$ A use for hydroxypropylmethyl cellulose (HPMC) $2 \%$, not mentioned by Lavin and Khaw, is when during ocular examination or surgery the internal view is obscured by phenylephrine epitheliopathy. ${ }^{23}$ Application of a layer of HPMC 2\% or sodium hyaluronate to the cornea results in a marked improvement in corneal clarity, which may be enough to prevent epithelial debridement having to be performed. \section{J D STEVENS
Moorfield Eye Hospital,
Road, London ECIV $2 P D$ City Road, London ECIV 2PD}

1 Lavin MJ, Khaw PT. Use of viscoelastic agents to aid visualisation during ocular surgery. $\mathrm{Br} \mathcal{F}$ Ophthalmol 1990; 74: 192 .

2 Edelhauser HF, Hine JE, Pederson $H$, Van Horn DL, Schultz RO. The effect of phenylephrine on the cornea. Arch Ophthalmol 1979; 97: 937-47. 3 Machemer R, Aaberg TM. Vitrectomy. 2nd ed. In: Machemer R, Aaberg TM, eds. New York: Grune and Stratton, 1979: 33.

\section{Reply}

SIR, - We did not specifically mention phenylephrine epitheliopathy when we outlined the use of hydroxypropylmethylcellulose (HPMC) to prevent corneal opacification, but would fully agree with $\mathrm{Mr}$ Stevens. In our experience the use of HPMC does improve the view through the cornea which may otherwise be obscured by topical drug induced epitheliopathy. With the use of HPMC on the cornea we have never had to perform an epithelial debridement on an eye with eyedrop-induced epitheliopathy during cataract surgery.

P T KHAW

$$
\begin{array}{r}
\text { P T KHAW } \\
\text { Institute of Ophthalmology, } \\
\text { Cayton Street, } \\
\text { London ECIV 9AT } \\
\text { M J LAVIN } \\
\text { Moorfields Eye Hospital, } \\
\text { City Road, } \\
\text { London ECIV2PD }
\end{array}
$$

